\title{
Role of PET/CT scan in identifying late-onset graft infection following Bentall procedure
}

\author{
Akash Batta (1) , ${ }^{1}$ Prashant Panda (10, ${ }^{1}$ Harpreet Singh, ${ }^{2}$ Yash Paul Sharma ${ }^{1}$
}

${ }^{1}$ Cardiology, Post Graduate Institute of Medical Education and Research, Chandigarh, India ${ }^{2}$ Nuclear Medicine, Post Graduate Institute of Medical Education and Research, Chandigarh, India

\section{Correspondence to} Dr Prashant Panda; prashantpanda85@gmail.com

Accepted 9 September 2021

Check for updates

(c) BMJ Publishing Group Limited 2021. No commercial re-use. See rights and permissions. Published by BMJ.

To cite: Batta A, Panda P, Singh $\mathrm{H}$, et al. BMJ Case Rep 2021;14:e243834. doi:10.1136/bcr-2021243834

\section{DESCRIPTION}

A 34-year-old man presented with fatigue for 3 months and fever for the last 1 month. His previous medical history was significant for Marfan syndrome and he had undergone Bentall procedure 10 years ago for type A aortic dissection. Postsurgery, he was lost to follow-up for the next 10 years until the current presentation. On examination, the pulse was good volume with a rate of $100 / \mathrm{min}$, blood pressure was $110 / 70 \mathrm{~mm} \mathrm{Hg}$ and the oral temperature was $102.3^{0} \mathrm{~F}$. General physical examination revealed a tall $(193 \mathrm{~cm})$, thin built individual with positive wrist and thumb sign and pectus carinatum deformity (figure $1 \mathrm{~A}-\mathrm{C}$ ). Cardiac examination revealed a grade $4 / 6$ pan-systolic murmur over the apex, radiating to the axilla.

Chest X-ray revealed cardiomegaly and ECG showed left ventricular hypertrophy (figure 1D). His laboratory parameters showed elevated leucocyte count $\left(14000 / \mathrm{mm}^{3}\right)$, raised $\mathrm{C}$ reactive protein (CRP) $(34 \mathrm{mg} / \mathrm{L})$ and procalcitonin $(2.1 \mathrm{ng} / \mathrm{mL})$. Transthoracic echocardiography (TTE) revealed dilated left atrium and left ventricle with a normally functioning prosthetic aortic valve. Additionally, there was anterior mitral leaflet prolapse with severe eccentric mitral regurgitation (figure $1 \mathrm{E}$ and F). As per the guidelines, transoesophageal echocardiography (TEE) is recommended for patients of suspected prosthetic valve endocarditis or in those with a high suspicion and an indeterminate TTE. ${ }^{1}$ Accordingly, TEE was performed to evaluate for mitral valve or prosthetic aortic valve endocarditis, but it was negative (figure 1G-I). Contrast-enhanced CT (CECT) chest and abdomen to look for other causes of fever was unremarkable (figure 2A and B).

However, when a pair of blood cultures grew methicillin-resistant Staphylococcus epidermidis, suspicion of graft/prosthetic valve infection was raised. Subsequently, positron emission tomography (PET)/CT revealed hypodense collection in the periaortic graft (maximum standardised uptake value-9.8) suggestive of active infection (figure 2C and $\mathrm{D})$. This confirmed the diagnoses of infective endocarditis. ${ }^{1} \mathrm{He}$ was started on intravenous vancomycin and gentamycin and oral rifampicin. Surgical intervention was offered, however, he refused. The fever responded by day 6 . Antibiotics were given for a duration of 12 weeks. The laboratory parameters including leucocyte count, CRP and procalcitonin normalised. Currently, the patient is doing fine at 6 months of follow-up, while on ramipril, $2.5 \mathrm{mg}$ and metoprolol $50 \mathrm{mg} /$ day. He has been recently referred for mitral valve repair in view of severe mitral regurgitation.

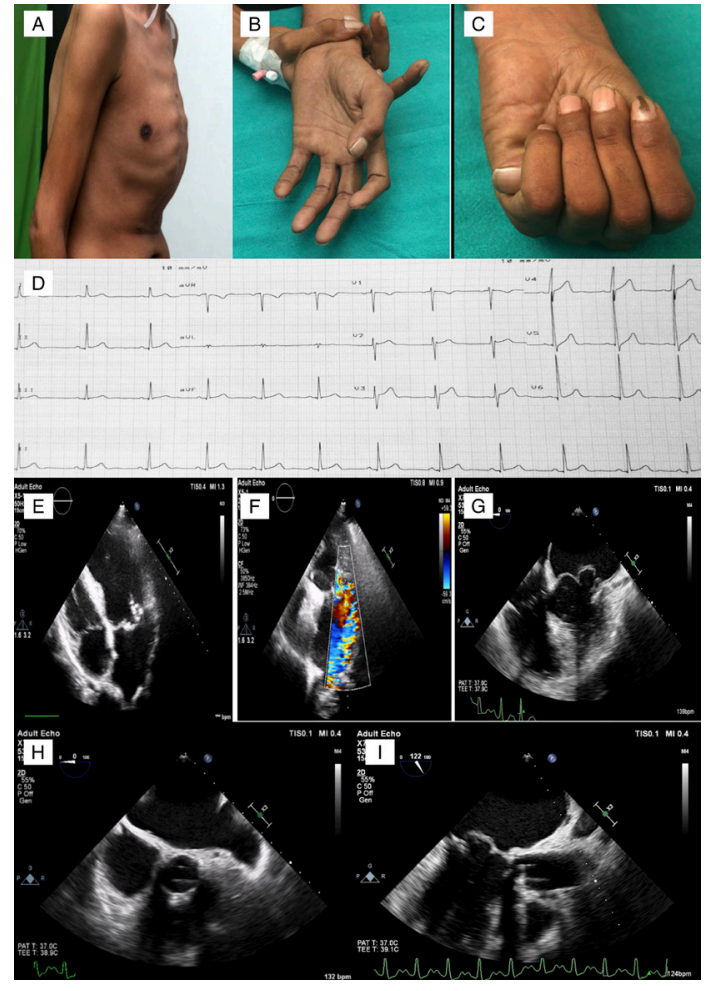

Figure 1 Clinical imaging showing pectus carinatum (A), positive wrist sign (B) and positive thumb sign (C). ECG revealed left ventricular hypertrophy (D). Transthoracic echocardiography images showing anterior mitral leaflet prolapse (E) with severe eccentric mitral regurgitation (F). Transoesophageal echocardiography images showing mitral valve prolapse without any vegetation on the leaflet $(\mathrm{G})$. Prosthetic aortic valve in short axis (H) and long axis (I) showing no evidence of periprosthetic infection/collection.

Infections are uncommon after the Bentall procedure, with an incidence of $1.4 \% .^{2}$ The diagnoses in these cases remain challenging and a variety of tests may be needed for confirmation. In general, CT and TEE have good accuracy for prosthetic valve and graft infections, ${ }^{3}$ but post-Bentall graft infection can be missed, ${ }^{4}$ like in the index case. PET/CT has shown to increase the sensitivity of the modified Duke criteria when combined with clinical, microbial and echocardiographic parameters. In the largest series on Bentall graft infection by Machelart et al, the sensitivity of CECT was $37.5 \%$ compared with PET/CT, which had a $100 \%$ sensitivity. ${ }^{4}$ The majority of infections are late onset and are caused by Gram-positive cocci. ${ }^{4}$ Surgery remains the preferred treatment option, however may not always be feasible given the complexity and highrisk nature of the procedure. ${ }^{5}$ Medical therapy with 


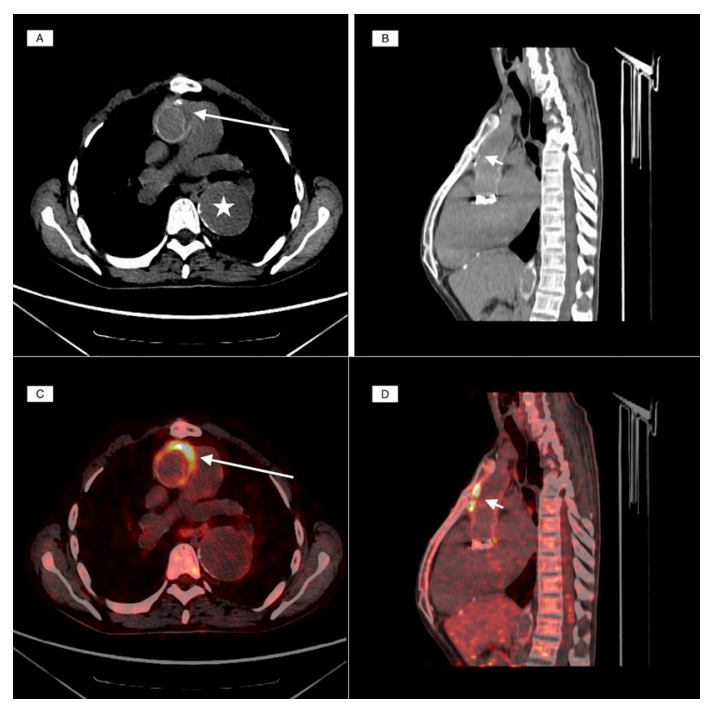

Figure 2 Axial (A) and sagittal cuts (B) of CT of the chest failed to identify any periaortic infection. Prosthetic aortic valve and graft extending till descending thoracic aorta can be seen (white star). Corresponding positron emission tomography cuts showing periaortic, vascular graft infection in axial (C) (long white arrows) and sagittal cuts (D) (short white arrows).

prolonged antibiotics ( $>3$ months) is effective in those who are not surgical candidates. PET/CT correlates poorly with clinical response and, hence, it is not recommended at follow-up. ${ }^{4}$

\section{Patient's perspective}

After the valve surgery, I was doing fine for the last 10 years. I had not had such a persistent and high fever all my life, and I was afraid. The doctors did lots of tests and were finally able to diagnose and treat me. I thank God and the entire treating team for getting me through this illness.

\section{Learning points}

- Graft infection post-Bentall is a rare but serious complication.

- Most infections are late onset and caused by Gram-positive cocci.

- A high index of suspicion is needed and positron emission tomography/CT may provide the only clue.

- Surgery may not be feasible in many cases, and longterm treatment with appropriate antibiotics is a suitable alternative.

Contributors $A B$ : original draft preparation, conceptualisation, reviewing and editing. PP: conceptualisation, methodology, investigation, supervision, validation, reviewing and editing. HS: original draft preparation, reviewing and editing. YPS: supervision, validation, reviewing and editing.

Funding The authors have not declared a specific grant for this research from any funding agency in the public, commercial or not-for-profit sectors.

Competing interests None declared.

Patient consent for publication Obtained.

Provenance and peer review Not commissioned; externally peer reviewed.

\section{ORCID iDs}

Akash Batta http://orcid.org/0000-0002-7606-5826

Prashant Panda http://orcid.org/0000-0002-2420-5209

\section{REFERENCES}

1 Li JS, Sexton DJ, Mick N, et al. Proposed modifications to the Duke criteria for the diagnosis of infective endocarditis. Clin Infect Dis 2000;30:633-8.

2 Joo H-C, Chang B-C, Youn Y-N, et al. Clinical experience with the Bentall procedure: 28 years. Yonsei Med J 2012;53:915.

3 Keidar Z, Nitecki S. Fdg-Pet for the detection of infected vascular grafts. Q J Nucl Med Mol Imaging 2009;53:35.

4 Machelart I, Greib C, Wirth G, et al. Graft infection after a Bentall procedure: a case series and systematic review of the literature. Diagn Microbiol Infect Dis 2017:88:158-62.

5 Saleem BR, Meerwaldt R, Tielliu IFJ, et al. Conservative treatment of vascular prosthetic graft infection is associated with high mortality. Am J Surg 2010;200:47-52.

Copyright 2021 BMJ Publishing Group. All rights reserved. For permission to reuse any of this content visit https://www.bmj.com/company/products-services/rights-and-licensing/permissions/

BMJ Case Report Fellows may re-use this article for personal use and teaching without any further permission.

Become a Fellow of BMJ Case Reports today and you can:

- Submit as many cases as you like

Enjoy fast sympathetic peer review and rapid publication of accepted articles

- Access all the published articles

Re-use any of the published material for personal use and teaching without further permission

Customer Service

If you have any further queries about your subscription, please contact our customer services team on +44 (0) 2071111105 or via email at support@bmj.com. Visit casereports.bmj.com for more articles like this and to become a Fellow 